Received 21.03.2017

Reviewed 06.05.2017

Accepted 16.05.2017

A - study design

B - data collection

C - statistical analysis

D - data interpretation

$\mathbf{E}$ - manuscript preparation

F - literature search

\title{
German support systems for onshore wind farms in the context of Polish acts limiting wind energy development
}

\author{
Leszek DAWID ${ }^{\mathrm{ABCDEF} \otimes}$
}

Technical University of Koszalin, Faculty of Civil Engineering, Environmental and Geodetic Sciences, ul. Śniadeckich 2, 75-453 Koszalin, Poland; e-mail: leszek.dawid@tu.koszalin.pl

For citation: Dawid L. 2017. German support systems for onshore wind farms in the context of Polish acts limiting wind energy development. Journal of Water and Land Development. No. 34 p. 109-115. DOI: 10.1515/jwld-20170044 .

\begin{abstract}
European energy system is undergoing a deep transition to low-emission energy sources, mainly wind farms. This transition is caused mostly by energy politics of European Union (EU) and its goals in the topic of renewable energy. European wind energy is dominated by Germany that produces half of total wind energy in EU. The aim of this article is to present support systems for wind farms existing in Germany in the context of introducing in Poland the Act of 20 May 2016 on Wind Energy Investments limiting onshore wind farms localization and Act of 22 June 2016 introducing changes to the Act on Renewable Energy Sources (RES) and some other acts. It is postulated to make amendments of acts regulating RES while considering German solutions.
\end{abstract}

Key words: Energiewende, renewable energy sources, wind energy, wind farms localization

\section{INTRODUCTION}

European energy system is undergoing a deep transition to low-emission energy sources, mainly wind farms. This transition is caused mostly by energy politics of European Union (EU) and its goals in the topic of renewable energy set for all its member states [Directive 2001/77/EC; Directive 2003/30/EC; Directive 2009/28/EC]. In 2015, the record-breaking number of new-build wind farms was registered in EU (see Fig. 1). The Fukushima nuclear disaster in 2011 also had impact on the wind farms development. In the wake of this incident German government decided to shut down all its nuclear plants by 2022 . The alternative approach to the German energy economy was renewable energy sources (RES). This decision on energy transition ended lasting over 50 years nuclear power debate in this country as well as hastened other governments' decisions on developing support systems for renewable energy sources.
On $25^{\text {th }}$ February 2015, the European Commission presented a communication titled "Framework Strategy for a Resilient Energy Union with a Forward-Looking Climate Change Policy". Its main goal is to create a fully integrated European energy system focused on developing modern low-emission technologies $[\mathrm{COM} / 2015 / 080]$. When it comes to integration of countries from the Baltic Sea Region, the important step took place when Denmark, Germany, Estonia, Latvia, Lithuania, Poland, Finland, and Sweden in June 2015 signed Memorandum of Understanding within the initiative of extending the Baltic Energy Market Interconnection Plan. This plan aims to deepen the cooperation in the energy sector between these countries what is of the utmost importance for maintaining security of energy supply in the region as well as effective use of RES [TPA Group 2015].

According to European Wind Energy Association (EWEA) combined power of wind farms installed in 
EU in the end of 2015 amounted to $12.8 \mathrm{GW}$, half of what came from Germany. When it comes to newbuilt wind turbines in 2015, Poland has second result in EU, after Germany (as seen on Fig. 1). However, when combined power from all installed wind farms is considered, in 2015 the biggest energy supply was registered in Germany (44.9 GW) and Spain (23.0 GW) (Fig. 2). Together they produced almost half of total wind energy in EU. They are followed by: United Kingdom (13.6 GW), France (10.4 GW) and Italy $(9.0 \mathrm{GW})$. Seventh place is taken by Poland, Portugal, and Denmark with similar installed wind power amounted to $\sim 5.1 \mathrm{GW}$ (also Fig. 2). Total wind energy in the end of 2015 equalled to over $11 \%$ of total energy production in EU [CORBETTA et al. 2016].

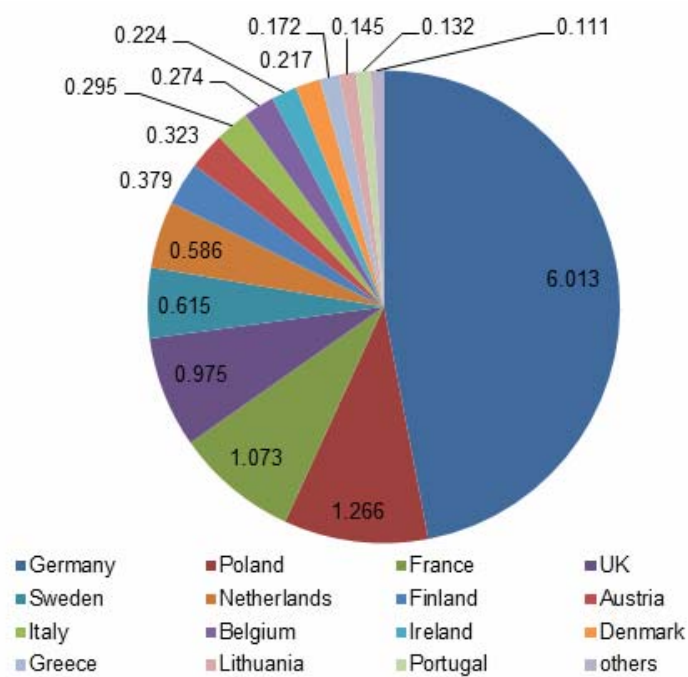

Fig. 1. Member states' share in power from wind farms built in 2015 (MW); source: own study based on statistics of CORBETTA et al. [2016]

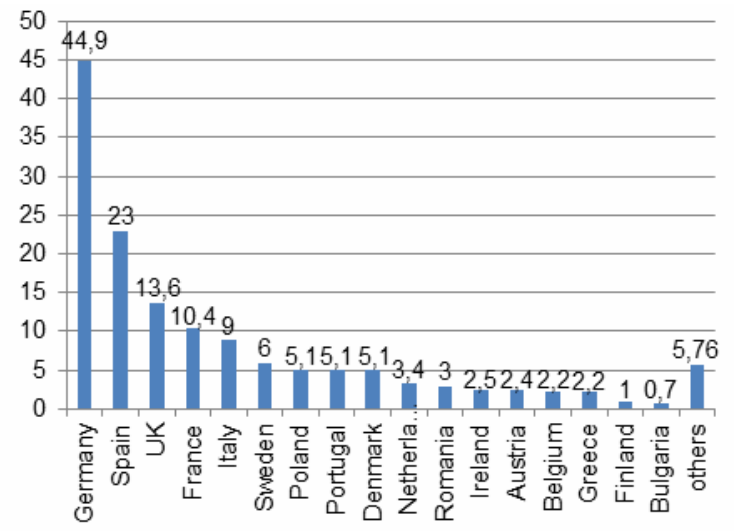

Fig. 2. Wind energy production in chosen EU members in the end of 2015; source: own study based on statistics of CORBETTA et al. [2016]

In many EU countries, wind energy is an important part of energy system, having a significant contribution to total energy production (see Tab. 1). Employment aspect is also not without relevance, as in whole EU 255 000 people work in this sector (see Tab. 1). In Germany, around 150000 workers are

Table 1. Wind power, wind energy contribution to total energy production, and number of employees in wind energy sector in the end of 2015 in the chosen EU countries

\begin{tabular}{|l|c|c|c|}
\hline Country & $\begin{array}{c}\text { Total wind } \\
\text { power } \\
\text { MW }\end{array}$ & $\begin{array}{c}\text { Wind energy } \\
\text { contribution to total } \\
\text { energy production, \% }\end{array}$ & $\begin{array}{c}\text { Number of } \\
\text { employees in wind } \\
\text { energy sector }\end{array}$ \\
\hline Germany & 44947 & 12.0 & 150.00 \\
\hline UK & 13603 & 11.0 & 30.00 \\
\hline France & 10358 & 4.0 & 12.52 \\
\hline Poland & 5100 & 6.2 & 8.40 \\
\hline $\begin{array}{l}\text { The Nether- } \\
\text { lands }\end{array}$ & 3431 & 5.6 & 10.15 \\
\hline UE & 141578 & 11.4 & 255.00 \\
\hline
\end{tabular}

Source: own study based on statistics of CORBETTA et al. [2016].

employed in wind energy sector, in UK - around 30 000, in Poland -8400.

Poland has very attractive grounds for wind farms along the Baltic Sea coast as well as in mountain regions in the south. It is due to the appropriate wind speed that is up to $10 \mathrm{~m} \cdot \mathrm{s}^{-1}$. Most of big Polish wind farms is in mentioned areas. Per report of EWEA [2013], good conditions for wind farms characterize grounds protected by Natura 2000 programme, but they are in fact excluded from possible investments by the law. These protected areas make up for around $32 \%$ of whole Poland's surface.

In Poland, the biggest part of energy production comes from coal - in 2015 it was over $83 \%$ [TPA Group 2015]. To reach goals set for Poland by EU (contribution from RES to total energy production equal $15 \%$ by 2020 ), investments in RES are necessary. To produce in 2020 around 32.4 TWh energy from RES, in years 2016-2020 its contribution needs to be increased by $10 \mathrm{TWh}$. Onshore wind energy is the cheapest source from all known RES.

The aim of this article is to present support systems for wind farms on the example of Germany, and in the context of introducing in Poland the Act of 20 May 2016 on Wind Energy Investments [Ustawa... 2016a] limiting wind farms localization as well as Act of 22 June 2016 introducing changes to the Act on Renewable Energy Sources and some other acts [Ustawa... 2016b]. As no offshore wind turbine has been built in Poland yet, the article is focused solely on onshore wind energy production.

\section{METHODS}

The research was done basing on the analysis of acts, regulations, the subject's literature, information from websites. The techniques of qualitative analysis of documents, and descriptive analysis were used. The base for choice of the analysis method was the type of gathered information. 


\section{RESULTS AND DISCUSSION}

Many UE members have created support systems for wind energy development [EWEA 2013]. They differ in both form and efficiency. Stability is a crucial element of such systems. In countries where regulations are unclear, unpredictable, and often changed (sometimes with retrospective effect), wind energy development is characterized by growth and drop cycles or is non-existent. Especially legislative environment needs a stable endorsement from the government [TPA Group 2015], which is often problematic due to social protests against wind farm localization. Financial support for onshore wind energy production among most of EU countries is similar, and between $7-10 \mathrm{ct} \cdot \mathrm{kWh}^{-1}$ [IEO 2012]. British system is an exception in this matter, as tariff depends on the installation size that is categorized into 7 types. Time period of such a support amounts usually to $15-20$ years. The biggest number of wind farms in last years has been built in Germany, therefore this country was chosen as a good example of state support systems for onshore wind energy development.

\section{ANALYSIS OF RES IN GERMANY}

Both German politicians and German society are known to widely support the wind energy development. German program of transition from nuclear power and fossil fuel to RES is commonly called as Energiewende [MORRIS, PEHNT 2014]. The program is based on four main principles: battle against climate's change, avoiding dangers of nuclear energy, improvement of energy security, and maintaining the development of competitive economy. Regular research on public opinion shows that Energiewende is continuously supported by over $90 \%$ of German citizens [Agora Energiewende 2016]. Due to beneficial regulations and lasting from year 2000 process of eliminating administrative barriers, a significant part of RES projects is still being developed. Wind farms are owned by subjects other than energy companies, such as private households, farmers, energy cooperatives. In 2012 citizen projects consisted in $46 \%$ of all RES installations, while share of big energy companies in the RES market amounted to only $13 \%$. Such an ownership structure as a significant reason of society wide support for Energiewende. Currently, politicians generally agree about closing the last nuclear power plant till 2022 and such a gradual increase of RES share in total energy production that till 2050 it amounts to at least $80 \%$. In Germany, apart from bonus for installations with high efficiency prolonging support by 5 years, also installations built in place of amortized and soon-to-be dismantled wind turbines are additionally supported (so-called repowering bonus) [IEO 2012].

\section{LEGISLATIVE SUPPORT IN GERMANY}

Building onshore wind farms higher than $50 \mathrm{~m}$ requires permits from number of institutions. It is necessary to evaluate an investment's impact on environment [Gesetz... 2010], and its legitimacy in the context of building laws of individual lands, respective communes' spatial planning, Federal Act on Nature Conservation and Landscape Management [Gesetz... 2009], The Air Traffic Law [Luftverkehrsgesetz... 2007], others. Main regulations on wind farm localization concern the noise (it must not exceed 55 $\mathrm{dB}$ in inhabited grounds during the day, $40 \mathrm{~dB}$ in the night, while on rural areas $-60 \mathrm{~dB}$ in daytime and 45 $\mathrm{dB}$ in night-time) [Baugesetzbuch... 2004] and shadow flickering (shadow projection cannot last longer than $30 \mathrm{~h}$ per year) [DEGÓRSKI (ed.) 2012]. Per par. $34 \S$ of [Baugesetzbuch... 2004], a proper body with a commune where wind farms are planned to be built both decide on admissibility of this investment. When it comes to wind farm localization, every land has its own regulations. For example, Schleswig-Holstein determines a distance between a wind turbine and exploited buildings to be equal 400 and $800 \mathrm{~m}$ (depending on a building's type) [DEGÓRSKI (ed.) 2012], Hamburg has different rules for housing estates $(500$ $\mathrm{m}$ ) and detached houses $(300 \mathrm{~m}$ ) [Offizielles Stadtportal für Hamburg 2010]. Investments in wind turbines lower than $50 \mathrm{~m}$ are regulated by building law. Process of obtaining a building permit differs between lands. Building permit is not needed if wind turbine is lower than $10 \mathrm{~m}$ [DEGÓRSKI (ed.) 2012].

Basis for energy wind development in Germany was created in the Act from 7th December 1990 on feeding electricity from renewable energy sources into the public grid (Electricity Feed-in Act, ger. Stromeinspeisungsgesetz) [Gesetz... 1990]. This act obliged electricity supply companies to buy RESbased energy from its producers for fixed price ( $\$ 2$ of [Gesetz... 1990]). On the $1^{\text {st }}$ April 2000, this act was replaced by Renewable Energy Sources Act (known also as EEG from its German name: ErneuerbareEnergien-Gesetz) [Gesetz... 2000], that inherited from its antecedent basic support instruments. German government got obliged in $\$ 65$ to evaluate, and monitor the progress, and prepare a report on its realisation for Federal Parliament every four years. This act caused sudden increase of investments in wind turbines, as RES-based electricity got priority in network access, and producers sell it for guaranteed price (so-called feed-in-tarrif). In 2009 Bundestag invoked the Renewable Energies Heat Act [Gesetz... 2000]. The aim of this act is to increase RES share in heat and cold production to $14 \%$ till 2020 . In 2010, the Energy And Climate Fund was created, aiming to ensure financial support for research on key branches of German energy strategy: RES, energy storage, its transport technology, electric cars and technologies that increase energy efficiency as well as decrease $\mathrm{CO}_{2}$ emission [BAJCZUK 2014]. In years 1990-2010 
wind energy production increased from $55 \mathrm{MW}$ to 27214 MW [DEGÓRSKI (ed.) 2012].

Next amendments of the act set a goal of increasing the share of RES in German economy [KWIATKOWSKA-DRÓŻDŻ (ed.) 2012] The EEG amendment in 2014 [Gesetz... 2000] contributed to a stable development of RES. Medium term targets are 40-45\% share of total electricity production coming from RES till 2025, and 55-60\% till 2035. Fixed-tariff system for RES is being kept up-to-date regularly, and is flexible in the context of different types of RES. In this amendment cost division between consumer groups was changed by lowering for example reductions for energy-intensive branches of industry. Integration of new RES installations was introduced such as: obligatory direct sale on spot market, freezing fixed-tariff in a period of negative energy prices (for over 6 hours in a row), introducing an auction system since 2017. In 2015 support for RES equalled to 21.5 billion euro [Agora Energiewende 2016].

However, electricity prices for German households are one of the highest in Europe (currently 30 eurocent $\cdot \mathrm{kWh}^{-1}$ ). The price increase was caused by increase of electricity sales tax, distribution charges and margin as well as by change of transmission tariff rate [SZYMALSKI 2015]. Germans reckon that RES cost will be decreasing, while conventional energy (including fossil fuel and nuclear power) cost will have unpredictable fluctuations with a distinct, longterm upward trend with an example of year 2013, when price of coal increased significantly.

\section{ANALYSIS OF RES IN POLAND}

Analysis of an ownership structure of wind farms in Poland allows to state that most of them - almost $80 \%$ of all wind investments - belongs to so-called IPP (Independent Power Producers). Among all wind power installed in Poland till the end of 2015, 19\% belongs to State Treasury companies (PGE Energia Odnawialna - 529 MW, Tauron Ekoenergia - 200.75 MW, Energa - $185 \mathrm{MW}$ and ENEA - 56 MW [TPA Group 2015]).

Before the change of the Act on Renewable Energy Sources [Ustawa 2015], the main instrument of support for RES installations in Poland were so-called green certificates being under control of Energy Regulatory Office. Certificates were bought on Polish Power Exchange by companies obliged to buy RES-based energy. The certificate value was expressed in percentile amount of electricity sold to final consumers. If companies didn't fulfil that obligation, they were charged with replacement payment set by Energy Regulatory Office [TPA Group 2015]. In years 2014-2015 green certificates' prices were around 100 PLN per $1 \mathrm{MWh}$.

\section{ACT ON RENEWABLE ENERGY SOURCES AND ITS RESOLUTIONS}

Act of 20th March 2015 on Renewable Energy Sources [Ustawa... 2015] replaced green certificate system with auction mechanism [TPA Group 2015], that was based on recommendations and guidelines of EU [SWD (2013) 439 final]. The government was supposed to announce auctions on green energy, reporting earlier in appropriate communications the amount of energy that would be bought from producers as well as a maximum (reference) price that cannot have been overstepped in an auction by a seller. Winners were meant to have a guaranteed price for produced energy for next 15 years. This act was a result of a compromise. The project was prepared not only by senators and deputies, but also by urbanists, architects, and representatives of self-government and branches that was to be impacted the most by the new regulations [TPA Group 2015]. Introduced standards concerning maximum noise levels resulted among others from the Regulation of the Minister of Environment on permitted levels of noise in the environment [Rozporządzenie MŚ... 2014]. Act on Renewable Energy Sources [Ustawa... 2015] assumed a total reconstruction of a system supporting "green electricity" production. Legislative works had lasted for 4 years. Most of new regulations entered into force on the $4^{\text {th }}$ May 2015 when the act was announced in Journal of Laws, but many key laws (especially the one concerning the new support system for RES, described in chapter 4) were meant to become effective on the $1^{\text {st }}$ January 2016. In the end of 2015, a new government made a fast amendment to the Act on RES, that postponed chapter 4 entering into force till $1^{\text {st }}$ July 2016.

\section{CURRENT LEGAL REGULATIONS CONCERNING RES}

Since $1^{\text {st }}$ July 2016 a new act on RES has been effective [Ustawa... 2016b]. In the act that had been effective so far, there were so-called fixed tariffs. They allowed to calculate a profitability of an investment. In the new act instead a reduction (discount) is introduced. $80 \%$ reduction is offered when RES-based energy is bought by a prosument owning microinstallations to $10 \mathrm{~kW}$. For owners of installations with power between 10 and $40 \mathrm{~kW}$, reduction of $70 \%$ is given (art. 4.1.). Microinstallations are obliged by the new act to give away any excess energy for free to energy companies which in turn can sell it to other final consumers. The new act introduced also a subject named 'prosument'. A prosument (art. 1i) is a final energy consumer (not a natural person), who also produces RES-based energy to use it for its own needs, but not connected to conducted business activities. For bigger economic subjects, auction system instead of fixed tariffs is designed (art. 39 and following). The biggest support is offered then to the most stable energy producers i.e. coal power plants. Also, 
a transition charge is increased in the new act. It can amount even to 50 PLN per year for one household [Green Projects 2016]. As a result, the new act on RES in fact favours conventional coal-based energy.

Act of 20 May 2016 on Wind Energy Investments was the next act that slowed down the wind energy development [Ustawa... 2016a]. It became effective on the $16^{\text {th }}$ July 2016 . Before this day, wind farm localization was not regulated by only one act - it had to meet conditions set by in many regulations concerning among others protection of environment, health, agricultural and forest grounds, and spatial planning and land development. The new act introduced many changes, including ones concerning conditions of wind farm localization. Per art. 3 of the act [Ustawa... 2016a] the location of the wind farm must be designated solely in the Local Zoning Plan. According to art. 4 par. 1 of this act, the distance between the wind turbine and households or buildings with mixed purpose that includes housing purpose should be equal or higher than ten times the total height of the wind turbine measured from the ground level to the highest point of the turbine, including technical equipment, especially hub with rotor blades. The act also introduces a few changes in the Building Law [Ustawa... 1994]. The most important ones are the following: deletion of dividing a wind turbine into a structural part and non-structural part, passing the authority of giving permits for wind turbine construction from mayor to province governor, indication that a wind turbine falls into the XXIX category of building objects and therefore requires a final decision containing a permit to use it. Keeping distance is also required when locating and constructing the wind farm in the proximity of forms of environmental protection.

\section{THE IMPACT OF DESCRIBED CHANGES ON WIND ENERGY DEVELOPMENT IN POLAND}

Newly introduced acts and regulations will cause a suspension of investments in onshore wind farms. Act on Wind Energy Investments [Ustawa... 2016a] with its regulations on wind farm localization make new wind farm investments in fact impossible. They are also a reason why replacement of many already working wind farms with more efficient devices after their complete exploitation is extremely difficult. Because of the change of 'non-building structure' definition in the Building Law, costs of insurance, inspections and property taxes will increase. As a result, owners of already existing wind turbines will be charged with much higher operative costs then nowadays. According to TPA Horwath [2016] analysis, typical ROI will drop from $7.1 \%$ to $0.7 \%$ i.e. much below a profitability of an investment. New Act on RES [Ustawa... 2016b] discourages potential small investors from RES-based electricity production, as energy can be produced e.g. in microinstallations only for their own needs (non-connected to their business activity), and its excess is to be given away for free to energy companies. Also, currently most of wind farms are owned by big energy companies, so the society has no personal interest in supporting the wind energy production. As a result, Polish support systems for onshore wind energy production are almost nonexistent. The coal-based energy has a lot more endorsement from the current government, increasing air pollution in many Polish cities notwithstanding [Polski Alarm Smogowy 2017]. The new acts are also the reasons why Poland will have great difficulties in meeting EU's guidelines concerning RES-based energy. There are perhaps two solutions. First is to introduce support systems for wind farms inspired by the German model when it comes to ownership structure, regulations on wind farm localization, economical bonuses, fixed tariff systems and others. The second is to develop of offshore wind farms [MARCINIAK et al. 2016].

\section{CONCLUSIONS}

\section{Germany}

1. Wind farms are owned by subjects other than energy companies. Such an ownership structure as a significant reason of society wide support for Energiewende and wind farms localization near housing estates. Apart from economical reasons, the society is convinced that such a way of energy production is the least invasive for the environment.

2. Apart from a bonus for installations with high efficiency prolonging support by 5 years, also installations built in place of amortized and soon-to-be dismantled wind turbines are additionally supported, what favours investments in more efficient and modern technologies what in change is related to increase in wind farms power.

3. Main regulations on wind farm localization concern the noise and shadow flickering. When it comes to wind farm localization, every land has its own regulations. The admissibility of the wind farm investment is decided by both a proper administrative body with a commune where wind farms are planned to be built.

4. German legislation obliges companies dealing with energy supply to buy first of all RES-based electricity for a fixed price.

5. Fixed-tariff system for RES is being kept upto-date regularly, and is flexible in the context of different types of RES.

\section{Poland}

1. Most of wind farms are owned by big energy companies, so the society has no personal interest in supporting the wind energy production. There is also wide endorsement for coal power plant development, even though air condition in many Polish cities is dangerously worsening.

2. Because of last amendments, owners of already existing wind turbines will be charged with much higher operative costs then nowadays, and typical ROI will drop below a profitability of wind turbine investment. 
Also, a replacement of a exploited wind turbine with a new, more modern one was made difficult.

3. New Act on RES discourages small investors from RES-based electricity production, as energy must be given away for free to energy companies, and then bought back with a reduced price.

4. The amendments of acts concerning RES and wind farm localizations should be made, while considering German solutions. Also, investments in offshore wind energy production were proposed.

\section{REFERENCES}

Agora Energiewende 2016. Understand the Energiewende. FAQ on the ongoing transition of the German power system [online]. [Access 10.01.2017]. Berlin pp. 69. Available at: www.agora-energiewende.de

BAJCZUK R. 2014. Odnawialne źródła energii w Niemczech. Obecny stan rozwoju, grupy interesu i wyzwania [Renewable energy sources in Germany. Up-to-date development state, interested groups, and challenges]. Warszawa. Ośrodek Studiów Wschodnich pp. 69.

Baugesetzbuch (BauGB) in der Fassung der Bekanntmachung vom 23. September 2004 [Act of 23 September 2004 - The Building Law]. BGB1. I S. 2414.

$\mathrm{COM} / 2015 / 080$. Communicaton from the Commission to the European Parliament, the Council, the European Economic and Social Committee, the Committee of the Regions, and the European Investment Bank: A framework strategy for a Resilient Energy Union with a Forward-Looking Climate Change Policy.

Corbetta G., Mbistrova A., Ho A. 2016. Wind in power: 2015 European statistics. Brussels. European Wind Energy Association pp. 14.

DEGÓRSKI M. (ed.) 2012. Energetyka wiatrowa w kontekście ochrony krajobrazu przyrodniczego i kulturowego w województwie kujawsko-pomorskim. [Wind energy in the context of natural and cultural landscape protection in the kujawsko-pomorski district]. Ekspertyza wykonana przez Instytut Geografii i Przestrzennego Zagospodarowania im. Stanisława Leszczyckiego, Polskiej Akademii Nauk na zlecenie Urzędu Marszałkowskiego Województwa Kujawsko-Pomorskiego w Toruniu. Warszawa pp. 148

Directive 2001/77/EC of the European Parliament and of the Council of 27 September 2001 on the promotion of electricity produced from renewable energy sources in the internal electricity market. EU OJ L 283, $27 / 10 / 2001$.

Directive 2003/30/EC of the European Parliament and of the Council of 8 May 2003 on the promotion of the use of biofuels or other renewable fuels for transport. EU OJ L $123,17 / 05 / 2003$.

Directive 2009/28/EC of the European Parliament and of the Council of 23 April 2009 on the promotion of the use of energy from renewable sources and amending and subsequently repealing Directives 2001/77/EC and 2003/30/EC. EU OJ L 140/16, 05/06/2009.

EWEA 2013. Wiatr ze wschodu: Wschodzace europejskie rynki energetyki wiatrowej [Wind from the east: European rising markets of wind energy]. Brussels. European Wind Energy Association pp. 16.

Gesetz für den Vorrang Erneuerbarer Energien (Erneuerbare-Energien-Gesetz - EEG) [Act of 29 March 2000 on Renewable Energy Sources]. BGBl. I S. 305 with further amendments.
Gesetz über die Einspeisung von Strom aus erneuerbaren Energien in das öffentliche Netz (Stromeinspeisungsgesetz) vom 07. Dezember 1990 [Act of 7 December 1990 on feeding electricity from renewable energy sources into the public grid (Electricity Feed-in Act)]. BGBl. I S. 2633 with further amendmends.

Gesetz über die Umweltverträglichkeitsprüfung (UVPG) in der Fassung der Bekanntmachung vom 24. Februar 2010 [Act of 24 February 2010 on Environmental Impact Assessment]. BGBl. I S. 94.

Gesetz über Naturschutz und Landschaftspflege (Bundesnaturschutzgesetz - BNatSchG) vom 29. Juli 2009 [Act of 29 July 2009 on Nature Conservation and Landscape Management]. BGB1. I S. 2542.

Green Projects 2016. Nowa ustawa o odnawialnych źródlach energii [New act on renewable energy sources] [online]. [Access 20.01.2017]. Available at: http:// www.green-projects.pl/2016/07/nowa-ustawa-oodnawialnych-zrodlach-energii

IEO 2012. Analiza możliwości wprowadzenia systemu feed-in tariff dla mikro i małych instalacji OZE. [Analysis of possibility of introducing a feed-in tariff system for micro- and small RES installations]. Ekspertyza wykonana przez Instytut Energetyki Odnawialnej na zlecenie Ministerstwa Gospodarki. Warszawa. Instytut Energetyki Odnawialnej pp. 92.

KwIATKOWSKA-DrożDŻ A. (ed.) 2012. Niemiecka transformacja energetyczna. Trudne początki [German energy transition. Difficult beginnings]. Ośrodek Studiów Wschodnich. Warszawa. ISBN 978-83-62936-17-5 pp. 107.

Luftverkehrsgesetz (LuftVG) in der Fassung der Bekanntmachung vom 10. Mai 2007 [Act of 10 May 2007 - The Air Traffic Law]. BGB1. I S. 698.

Marciniak T., Purta M., Rozenabaum K. 2016. Rozwój morskiej energetyki wiatrowej w Polsce. Perspektywy i ocena wpływu na lokalną gospodarkę [Offshore wind energy development in Poland. Perspectives and evaluation of its impact on local economy]. Warszawa. McKinsey \& Company pp. 36.

Morris C., Pehnt M. 2014. Energy Transition: The German Energiewende pp. 105.

Offizielles Stadtportal für Hamburg. 2010. Ausschlussgebiete für Windkraftanlagen in Hamburg [Areas excluded from wind farms localization in Hamburg] [online]. [Access: 30.01.2017] Available at: http://www. hamburg.de/contentblob/2642064/data/f-xx-xxwindenergieanlagen-ausschlussgebiete.pdf

Polski Alarm Smogowy 2017. Smog [Smog] [online]. [Access: 30.01 .2017$]$. Available at: http://www.polskialarm smogowy.p1/

PSEW 2015. Stan energetyki wiatrowej w Polsce w 2015 roku [Energy wind in Poland in 2015]. Warszawa. Polskie Stowarzyszenie Energetyki Wiatrowej pp. 75.

Rozporządzenie Ministerstwa Środowiska z dnia 14 czerwca 2007 r. w sprawie dopuszczalnych poziomów hałasu w środowisku [Regulation of the Minister of Environment of 14 June 2007 on permitted levels of noise in the environment]. Dz.U. 2014 poz. 112.

SWD (2013) 439 final. European Commission guidance for the design of renewables support scheme.

SZYMALSKI W. 2015. Niemiecka transformacja energetyczna: fakty [German energy transitions: Facts]. Warszawa. Instytut na rzecz Ekorozwoju, Fundacja im. Heinricha Bölla pp. 15.

TPA Group 2015. Raport: Energetyka wiatrowa w Polsce [Report: Wind energy in Poland]. Warszawa pp. 41. 
TPA Horwath 2016. Wybrane efekty wstrzymania inwestycji w sektorze lądowej energetyki wiatrowej [Chosen effects of suspense in investments in wind energy]. [online]. [Access 22.01.2017]. Warszawa. PSEW pp. 26. Available at: http://psew.pl/wp-content/uploads/ 2016/12/69dde02bb447567fca09d7e243ff21f4.pdf

Ustawa z dnia 7 lipca 1994 r. Prawo budowlane [Act of 7 July 1994 - The Building Law]. Dz.U. 2013 poz. 1409 with further amendmends.
Ustawa z dnia 20 marca 2015 r. o odnawialnych źródłach energii [Act of 20 February 2015 on Renewable Energy Sources]. Dz.U. 2015 poz. 478.

Ustawa z dnia 20 maja 2016 r. o inwestycjach w zakresie elektrowni wiatrowych [Act of 20 May 2016 on Wind Energy Investments]. Dz. U. 2016 poz. 961.

Ustawa $\mathrm{z}$ dnia 22 czerwca 2016 r. o zmianie ustawy o odnawialnych źródłach energii oraz niektórych innych ustaw [Act of 22 June 2016 introducing changes to the Act on Renewable Energy Sources and some other acts]. Dz.U. 2016 poz. 925.

\section{Leszek DAWID}

\section{Niemieckie systemy wsparcia farm wiatrowych na lądzie w kontekście polskich ustaw ograniczających rozwój energetyki wiatrowej}

\section{STRESZCZENIE}

System energetyczny w Europie przechodzi głęboką transformację w kierunku niskoemisyjnych źródeł energii, głównie farm wiatrowych. Rozwój ten w dużej mierze spowodowany jest polityką energetyczną Unii Europejskiej (UE) i jej celami w zakresie energii odnawialnej. W kategorii energii wiatrowej prym wiodą Niemcy, których farmy wiatrowe produkują połowę całkowitej energii wiatrowej UE. Celem artykułu jest przedstawienie systemów wsparcia rozwoju farm wiatrowych na przykładzie Niemiec i w kontekście wprowadzenia w Polsce ustawy z dnia 20 maja 2016 r. o inwestycjach w zakresie elektrowni wiatrowych ograniczającej lokalizację farm wiatrowych na lądzie oraz ustawy z dnia 22 czerwca 2016 r. o zmianie ustawy o odnawialnych źródłach energii (OZE), a także niektórych innych ustaw. Postuluje się zmianę ustaw regulujących OZE i wprowadzenie w Polsce systemów wsparcia na wzór niemiecki.

Słowa kluczowe: Energiewende, farmy wiatrowe, lokalizacja farm wiatrowych, odnawialne źródta energii 